\title{
Mechanism of Bone-like Apatite Formation on Anodised Titanium under UV Irradiation
}

\author{
T.C. Lee, H.Z. Abdullah, and M.I. Idris
}

\begin{abstract}
Anodic oxidation is an electrochemical method for the production of ceramic films on a metallic substrate. It had been widely used to deposit the ceramic coatings on the metals surface. UV light was used to accelerate the bone-like apatite formation on the anodised titanium in this study. The processing was composed of two steps which were UV light treatment after anodic oxidation, and UV light illumination during simulated body fluid (SBF). This study aims to study the mechanism of bone-like apatite formation on the surface of anodised titanium under UV irradiation. High purity titanium foils were anodised at $350 \mathrm{~V}, 70 \mathrm{~mA} \cdot \mathrm{cm}^{-2}$ in electrolytic solution containing glycerophosphate disodium salt pentahydrate $(\beta$ GP) and calcium acetate monohydrate (CA) for 10 minutes. UV light treatment was conducted in $\mathbf{p H}$-adjusted distilled water (pH 1) for 12 hours. Next, SBF was carried out by illuminating with UV lamp for 1 week. Anodised titanium foils were characterised by using field emission scanning electron microscopy (FESEM) and fourier transform infrared spectroscopy (FTIR). The results showed that bone-like apatite started to form at concave surface due to the presence of nucleation site. The surface of anodised titanium was fully covered by bone-like apatite after soaking in SBF for 4 days. Denser bone-like apatite was formed after 7 days immersion in SBF. The mechanism of the growth of bone-like apatite was illustrated. The FTIR results showed that carbonated bone-like apatite was formed on the surface on anodised titanium. The result indicated that the anodised titanium in mixture of $\beta$-GP $+\mathrm{CA}$ possess excellent apatite-forming ability under UV irradiation.
\end{abstract}

Keywords - anodic oxidation, titanium, titanium dioxide, UV irradiation, simulated body fluid, bone-like apatite.

\section{Introduction}

Titanium and its alloys have become one of the popular biomaterials for implants application due to its properties such as biocompatibility, promote osseointegration, good mechanical properties, low modulus of elasticity and high corrosion resistance [1-5]. A thin and passive titanium dioxide $\left(\mathrm{TiO}_{2}\right)$ with $1.5-10 \mathrm{~nm}$ thickness will be formed after titanium metal exposed to atmospheric condition [6].

Naturally, $\mathrm{TiO}_{2}$ exist in three crystalline phases which are anatase, brookite and rutile. Rutile form is the most common and stable form among all the crystallographic forms. The band gap for anatase and rutile $\mathrm{TiO}_{2}$ are $3.20 \mathrm{eV}$ and $3.02 \mathrm{eV}$, respectively [7]. It is reported that the anatase and rutile form of $\mathrm{TiO}_{2}$ are more active in photocatalysis if compared to brookite form [8].

$\mathrm{TiO}_{2}$ is an ideal photocatalyst due to its superior properties such as high stability, low cost, high photocatalytic performance and strong oxidation ability [9].

Maizlinda Izwana Idris

Universiti Tun Hussein Onn Malaysia

Malaysia
Recently, UV irradiation has been used to enhance the osseointegration capability of titanium [10,11]. This is because of $\mathrm{TiO}_{2}$ is an attractive photocatalyst which will generate electron-hole pairs during UV irradiation. The electron tends to reduce $\mathrm{Ti}^{4+}$ to $\mathrm{Ti}^{3+}$ and the holes are trapped by surface $\mathrm{H}_{2} \mathrm{O}$ to yield hydroxyl groups $(\cdot \mathrm{OH})$. The - $\mathrm{OH}$ groups produced during photocatalysis provide active sites for bone-like apatite formation [12-15].

A number of efforts have been done to modify the surface of titanium in order to accelerate the osseointegration, such as anodic oxidation, alkaline treatment, gel oxidation and plasma spray. Anodic oxidation combines electric field driven metal and oxygen ion diffusion for formation of oxide layer on the anode surface [3-5]. The oxide layer $\left(\mathrm{TiO}_{2}\right)$ is formed due to the migration of $\mathrm{O}_{2}$ ions into the titanium interface and migration of the $\mathrm{Ti}^{4+}$ ions from the titanium to the film/electrolyte interface. The advantages of anodic oxidation are relatively simple, low cost, enhance the adhension and bonding, improve crystallinity and increase the corrosion resistance of oxide layer [6]. After implantation, anodised titanium will form a bone-like apatite layer on the surface in order to the bond with living bone. The composition and structure of bone-like apatite is very similar to the human bone [16].

In this study, the mixture of $\beta-\mathrm{GP}+\mathrm{CA}$ was used as electrolyte. This mixture has been widely used in food industries as food stabiliser [2]. In term of biomedical application, it provides phosphorous and calcium ions which will promote the bone tissue growth and enhance anchorage of the implant to bone [3]. However, anodic oxidation of titanium with $\beta-G P+C A$ requires long time period to form bone-like apatite on the surface. This is due to the lack of nucleation site for the growth of bone-like apatite. Therefore, UV irradiation was proposed in our previous works in order to activate the nucleation site and accelerate the formation of bone-like apatite in 7 days [13-15].

In this research, UV light was used to accelerate the formation of bone-like apatite on the anodised titanium. The processing was composed of two steps which were UV light treatment after anodic oxidation, and UV light illumination during SBF. This study aims to investigate the mechanism of bone-like apatite formation on anodised titanium under UV irradiation.

\section{Experimental Method}

\section{A. Sample Preparation}

High-purity titanium foils with dimension of $25 \mathrm{~mm}$ x 10 $\mathrm{mm} \times 0.05 \mathrm{~mm}$ were wet hand polished with 1200 grit abrasive paper $(\sim 1 \mu \mathrm{m})$ to remove native layer, and then immersed in an ultrasonic bath with acetone. Next, the titanium foils were rinsed with distilled water and dried using compressed air. Anodic oxidation was done by using programmable power supply (Genesys 600-1.3, Densei- 
Proc. of the Third Intl. Conf. Advances in Civil, Structural and Mechanical Engineering- CSM 2015

Copyright $($ Institute of Research Engineers and Doctors, USA .All rights reserved.

ISBN: 978-1-63248-062-0 doi: 10.15224/ 978-1-63248-062-0-37

Lambda, Japan) in $400 \mathrm{ml}$ electrolytic solution. The electrolyte consist of mixture of $\beta$-GP (Sigma, $\geq 98.0 \%$ ) and $\mathrm{CA}(\mathrm{HmbG}, \geq 90.0 \%)$. The parameters used for anodic oxidation is tabulated in Table I. The anodised titanium foils were cleaned by dipping in distilled water, followed by drying in air. Subsequently, anodised foils were UV-treated with a UVA lamp (peak wavelength of $365 \mathrm{~nm}$ ) in $\mathrm{pH}$ adjusted distilled water ( $\mathrm{pH} 1)$ for 12 hours.

TABLE I. PARAMETER USED FOR ANODIC OXIDATION

\begin{tabular}{|c|c|}
\hline Parameter & Values(s) \\
\hline Electrolytes Concentration & $0.04 \mathrm{M} \beta$-GP $+0.4 \mathrm{M} \mathrm{CA}$ \\
\hline d.c voltage $(\mathrm{V})$ & 350 \\
\hline Current density $\left(\mathrm{mA} . \mathrm{cm}^{-2}\right)$ & 70 \\
\hline Duration $(\mathrm{min})$ & 10 \\
\hline Temperature $\left({ }^{\circ} \mathrm{C}\right)$ & $\sim 25$ \\
\hline
\end{tabular}

\section{B. Simulated Body Fluid}

Anodised titanium foils were cut into $15 \mathrm{~mm}$ x $10 \mathrm{~mm}$ x $0.05 \mathrm{~mm}$ and immersed in $20 \mathrm{ml}$ SBF (prepared by following Kokubo's recipe [17]), kept at $37{ }^{\circ} \mathrm{C}$ for 7 days and illuminated by UVA lamp to evaluate their bioactivity. The SBF was refreshed every two days so that lack of ions would not inhibit the apatite formation. After removal from SBF, the anodised titanium foils were washed with distilled water and air dried.

\section{Characterisation}

The microstructure was examined by using FESEM (JFM-7600F, Joel) at an accelerating voltage of $2.0 \mathrm{kV}$. Fourier transform infrared spectroscopy (Spectrum 100, PerkinElmer, USA) was used to examine the compound and structure of anodised titanium after soaking in SBF. The spectra were collected over the range $4000-530 \mathrm{~cm}^{-1}$.

\section{Results and Discussion}

\section{A. FESEM Observation}

The surface morphologies of the anodised titanium after being immersed in the SBF with UV irradiation for 1 to 7 days are shown in Fig. 1. The summary of surface morphologies for 1 to 7 days after soaking SBF is tabulated in Table II.

Photocatalysis occurred during the immersion in SBF with UV irradiation. The $\bullet \mathrm{OH}$ groups were produced after UV reacts with $\mathrm{TiO}_{2}$ during photocatalysis. Next, the $\cdot \mathrm{OH}$ groups combined with Ti to form Ti-OH groups. As a result, the surface of anodised titanium was changed to negatively charge. Negatively charged surface attracted the $\mathrm{Ca}^{2+}$ ions in $\mathrm{SBF}$ and combined with Ti-OH groups to form amorphous calcium titanate. After a long soaking time, phosphate ions $\left(\mathrm{PO}_{4}{ }^{3-}\right)$ were reacted with amorphous calcium titanate and form bone-like apatite.

Based on the results, it can be concluded that concave surface on the surface of anodised titanium provides more nucleation site for the growth of bone-like apatite. This behaviour is supported by the previous finding [18].
TABLE II. SUMMARY FOR SURFACE MORPHOLOGIES OF ANODISED TITANIUM BEFORE AND AFTER SOAKING IN SBF UNDER UV IRRADIATION

\begin{tabular}{|c|l|c|}
\hline Days & Observation/Description & Fig. \\
\hline $\begin{array}{c}\text { After } \\
\text { Anodisation }\end{array}$ & $\begin{array}{l}\text { Donut-shaped pores were formed due to the local } \\
\text { melting of oxide layer during anodic oxidation. }\end{array}$ & $1(\mathrm{~A})$ \\
\hline $1^{\text {st }}$ & $\begin{array}{l}\text { Small amount of bone-like apatite was } \\
\text { precipitated in the concave surface }\end{array}$ & $1(\mathrm{~B})$ \\
\hline $2^{\text {nd }}$ & $\begin{array}{l}\text { More bone-like apatite was precipitated in the } \\
\text { concave surface. }\end{array}$ & $1(\mathrm{C})$ \\
\hline $3^{\text {rd }}$ & $\begin{array}{l}\text { Bone-like apatite started to agglomerate and cover } \\
\text { all the pores on the surface of anodised titanium }\end{array}$ & $1(\mathrm{D})$ \\
\hline $4^{\text {th }}$ & $\begin{array}{l}\text { The entire surface of anodised titanium was } \\
\text { completely covered by bone-like apatite and } \\
\text { cracks were observed. This is due to the stresses } \\
\text { induced by the mismatch between the newly } \\
\text { formed bone-like apatite with the initial } \\
\text { precipitates. }\end{array}$ & $1(\mathrm{E})$ \\
\hline $5^{\text {th }}$ & $\begin{array}{l}\text { The bone-like apatite started to form layer } \\
\text { structure }\end{array}$ & $1(\mathrm{~F})$ \\
\hline $6^{\text {th }}$ & $\begin{array}{l}\text { Dense, spherical and island-like agglomerated } \\
\text { bone-like apatite was formed. Cracks were } \\
\text { observed. }\end{array}$ & $1(\mathrm{G})$ \\
\hline $7^{\text {th }}$ & $\begin{array}{l}\text { Denser bone-like apatite and cracks were } \\
\text { observed. }\end{array}$ & $1(\mathrm{H})$ \\
\hline
\end{tabular}

Nucleation site of bone-like apatite is the easiest to nucleate on the concave surface, followed by smooth surface and convex surface. This is due to the concave surface has negative charges and providing numerous nucleation sites for the growth of bone-like apatite. Thus, the bone-like apatite prefers to be formed in the concave surface. Apart from that, concave surface has high hydrophilicity and greater surface energy which will induced the formation of bone-like apatite. Once the nucleation site of bone-like apatite is formed, they can grow spontaneously by consuming the calcium and phosphate ions in the SBF. More Ti-OH groups were formed at the concave surface after UV light treatment and resulted the negative charges surface. As mention previously, the negative charged surface will attract the $\mathrm{Ca}^{2+}$ ions and $\mathrm{PO}_{4}{ }^{3-}$ in the $\mathrm{SBF}$ to form bone-like apatite. This is the reason why bone-like apatite was precipitated in the concave surface at initial stage. Even more, calcium and phosphorus-containing oxide layers is able to release calcium and phosphorous ions during immersion in SBF and accelerate the formation of bone-like apatite.

\section{B. FTIR Analysis}

The FTIR spectrum of anodised titanium after soaking in the SBF for 1 to 7 days is shown in Fig. 2. Based on the FTIR spectrum, after soaking in SBF for 1 to 4 days, anodised titanium only contains phosphate $\left(\mathrm{PO}_{4}{ }^{3-}\right)$ at $1015 \mathrm{~cm}^{-1}$. This results indicated that low crystalline and small amount of bone-like apatite was formed on the surface of anodised titanium. The carbonate $\left(\mathrm{CO}_{3}{ }^{2-}\right)$ absorption bands were observed at $1238 \mathrm{~cm}^{-1}, 1451 \mathrm{~cm}^{-1}, 1541 \mathrm{~cm}^{-1}$, and $1651 \mathrm{~cm}^{-1}$ after soaking in SBF for 5 days. Apart from that, the broad band centered at $2922 \mathrm{~cm}^{-1}$ and sharp peak at $1728 \mathrm{~cm}^{-1}$ were attributed to residual $\mathrm{H}_{2} \mathrm{O}$ during the formation of bone-like apatite. After soaking in SBF for 6 days, more carbonated absorption bands were detected. Meanwhile, the phosphate absorption band at $1015 \mathrm{~cm}^{-1}$ became sharper. In addition, the characteristic absorption bands at $1102 \mathrm{~cm}^{-1}$ and $960 \mathrm{~cm}^{-1}$ were detected and it suggest the presence of hydrogen phosphate $\left(\mathrm{HPO}_{4}{ }^{2-}\right)$ in the apatite. The phosphate absorption band at $1015 \mathrm{~cm}^{-1}$ became sharper after soaking in SBF for 7 days. The results indicated that anodised 


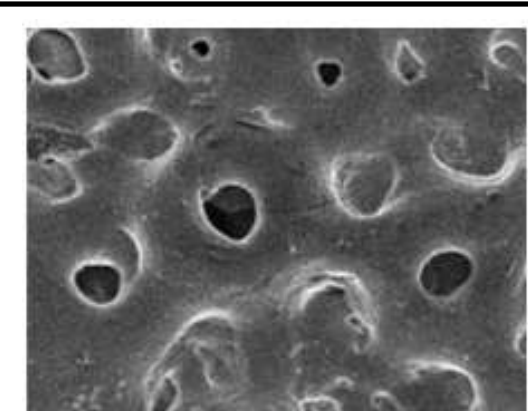

A

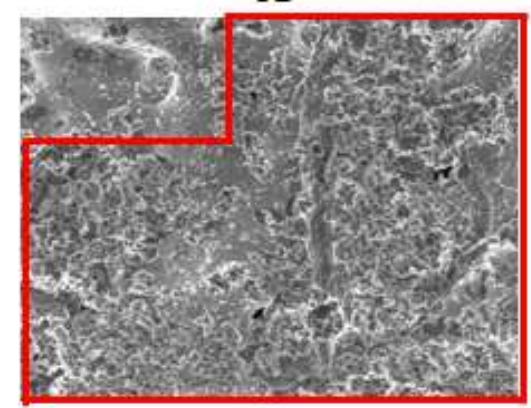

D

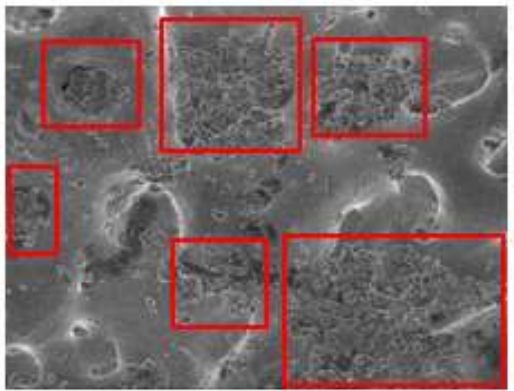

B

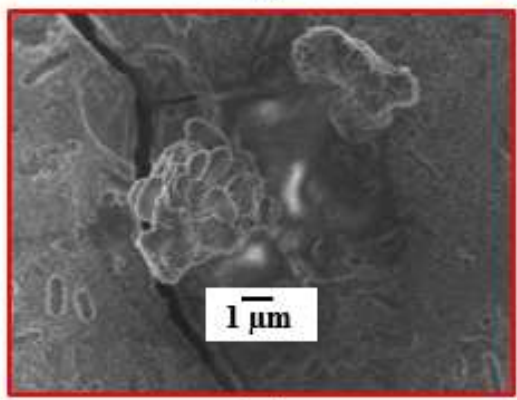

$\mathbf{E}$

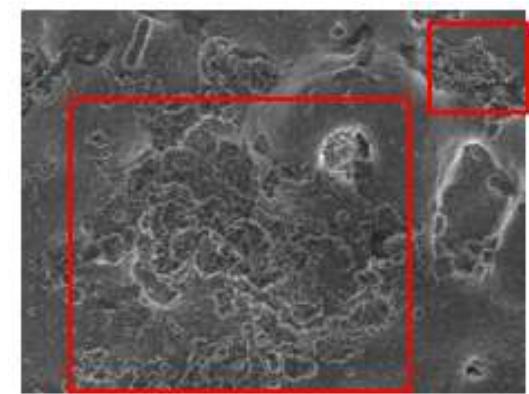

C

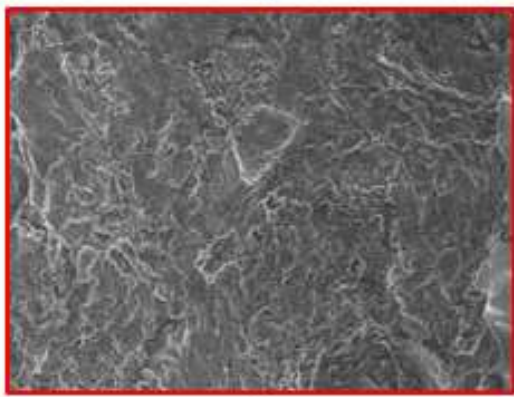

$\mathbf{F}$

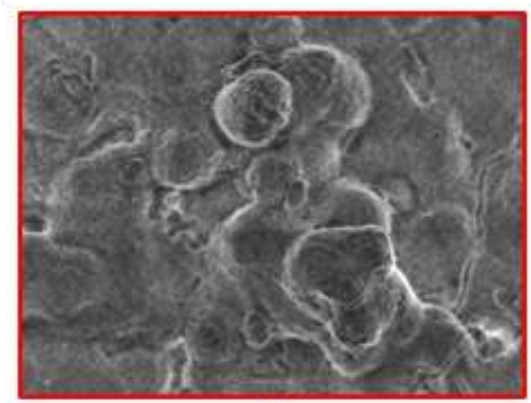

G

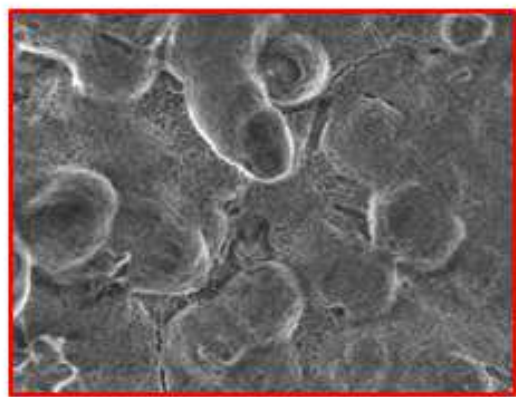

H

Fig. 1. Surface morphologies of anodised titanium (A) before soaking in SBF; and after soaking in SBF under UV irradiation for (B) 1 day; (C) 2 days; (D) 3 days; (E) 4 days; (F) 5 days; (G) 6 days; and (H) 7 days

titanium in mixture of $\beta$-GP and CA with UV irradiation during SBF is able to induce the formation of carbonated apatite.

\section{Mechanism of Bone-like Apatite Formation}

Fig. 3 shows the mechanism of bone-like apatite formation under UV irradiation illustrated by schematic diagram. The suggestion mechanism as follow:

1. Fig. 3(A): Small amount of bone-like apatite precipitated at concave surface

2. Fig. 3(B): Bone-like apatite started to agglomerate and became larger

3. Fig. 3(C): Bone-like apatite from difference concave surface combined and formed a flat layer. Cracks was observed due to the stresses induced by mismatch between the newly formed bone-like apatite with the initial precipitates.
4. Fig. 3(D): Denser bone-like apatite was formed after continuously immersion in SBF

\section{Conclusions}

In conclusion, UV light is a promising method to accelerate the growth of bone-like apatite. UV pre-treated anodised titanium showed remarkable bone-like apatite formation on their surface in SBF with UV irradiation after 7 days. Bone-like apatite started to precipitate at concave surface, where there provides nucleation site for the growth of bone-like apatite. The surface of anodised titanium was fully covered by bone-like apatite after 4 days immersion in SBF. Cracks were observed due to the stresses induced by the mismatch between the newly formed bone-like apatite with the initial precipitates. At the same time, FTIR results confirmed that the carbonated bone-like apatite was formed after immersion in SBF with UV irradiation. Combination of anodic oxidation, UV pre-treatment and UV irradiation during SBF provides a novel route to increase the formation of bone-like apatite on titanium implant. 
Proc. of the Third Intl. Conf. Advances in Civil, Structural and Mechanical Engineering- CSM 2015 Copyright (C) Institute of Research Engineers and Doctors, USA .All rights reserved.

ISBN: 978-1-63248-062-0 doi: 10.15224/ 978-1-63248-062-0-37

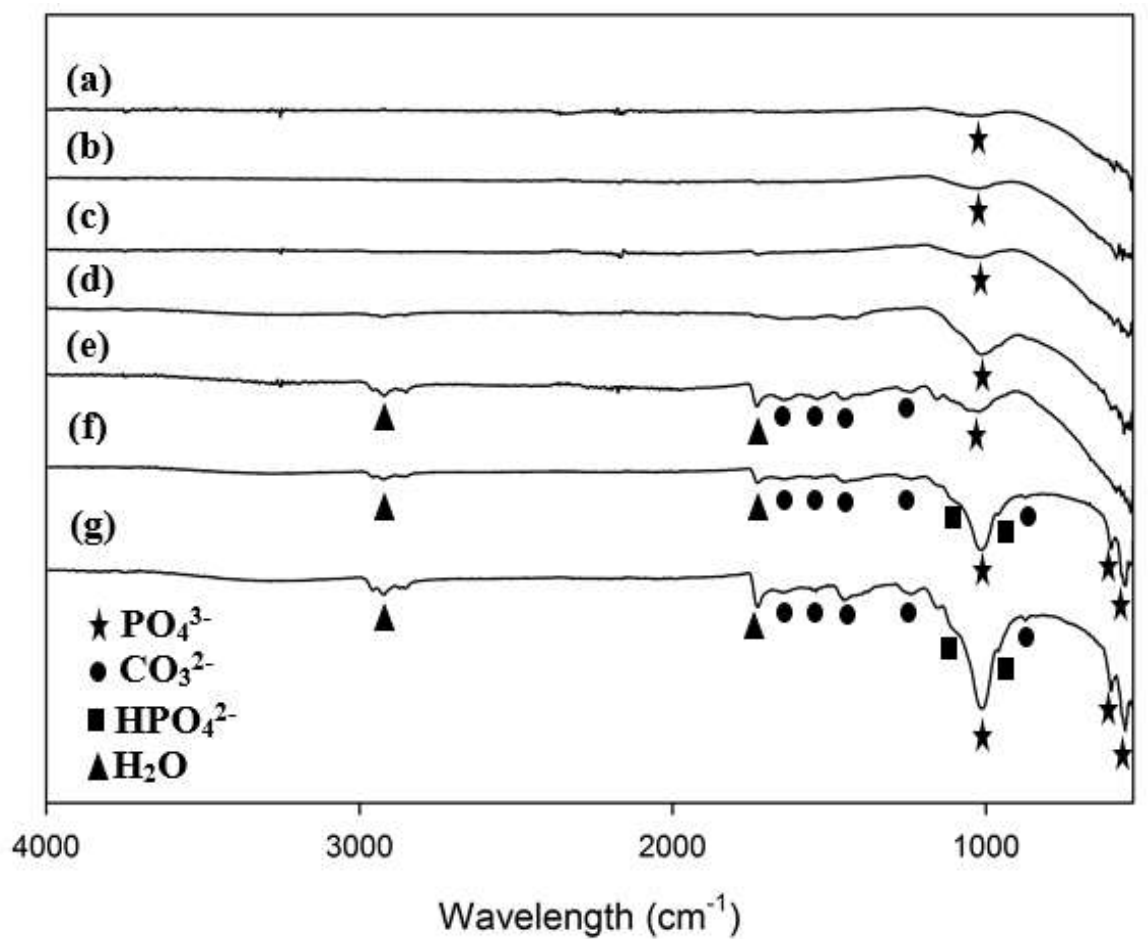

Fig. 2. FTIR spectra of anodised titanium after soaking in SBF under UV irradiation (A) 1 day; (B) 2 days; (C) 3 days; (D) 4 days; (E) 5 days; (F) 6 days; and $(\mathrm{G}) 7$ days.

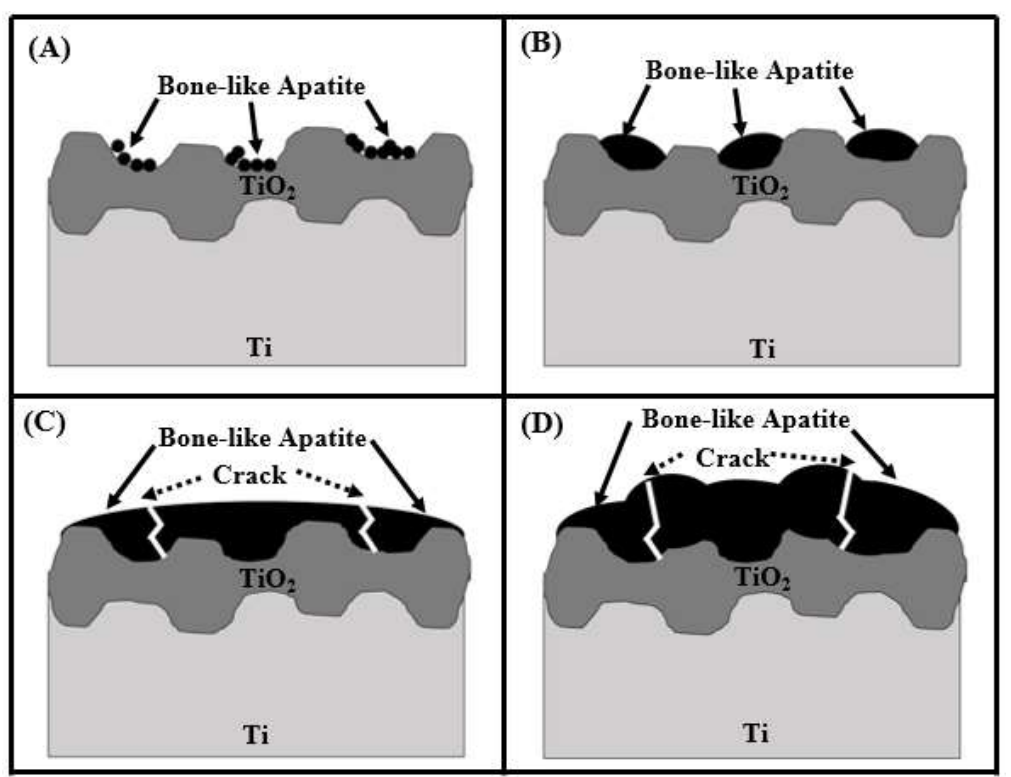

Fig. 3. Schematic of bone-like apatite formation in SBF under UV irradiation (A-D).

\section{Acknowledgment}

The authors gratefully acknowledge to Universiti Tun Hussein Onn Malaysia, Ministry of High Education Malaysia for the Research Acculturation Collaborative Effort (RACE Vot 1442) and Fundamental Research Grant Scheme (FRGS Vot 1212 \& Vot 1419).

\section{References}

[1] H.Z. Abdullah, and C.C. Sorell, "Preparation and characterisation of $\mathrm{TiO}_{2}$ thick films fabricated by anodic oxidation," Mater. Sci. Forum, vol. 561, pp. 2159-2162, 2007 .

[2] H.Z. Abdullah, T.C. Lee, M. I. Idris, and C.C. Sorrell, "Effect of current density on anodised titanium in mixture of $\beta$-glycerophosphate $(\beta-G P)$ and calcium acetate (CA)," J. Adv Mater. Res., vol. 1087, pp.212-217, 2015 .

[3] T.C. Lee, M.I. Idris, H.Z. Abdullah, and C.C. Sorrell, "Effect of electrolyte concentration on anodised titanium in mixture of $\beta$ glycerophosphate ( $\beta-\mathrm{GP})$ and calcium acetate (CA)", J. Adv Mater. Res., vol. 1087, pp.116-120, 2015.

[4] T.C. Lee, H.Z. Abdullah, and M.I. Idris, "Surface properties, crystallinity and optical properties of anodised titanium in mixture of 
$\beta$-glycerophosphate ( $\beta$-GP) and calcium acetate (CA)," Malaysian J. Micros., vol. 10, pp. 138-144, 2014.

[5] T.C. Lee, M.F.M. Rathi, M.Y.Z. Abidin, H.Z. Abdullah, and M.I. Idris, "Effect of applied voltage on surface properties of anodised titanium in mixture of $\beta$-glycerophosphate ( $\beta$-GP) and calcium acetate (CA)", Proceeding of $23^{\text {rd }}$ Sci. Conf. of the Micros. Soc. Malaysia, in press.

[6] H.Z. Abdullah, Titanium surface modification by oxidation for biomedical application: The University of New South Wales, Australia, 2010.

[7] D. a. H. Hanaor and C.C. Sorrell, "Review of the anatase to rutile phase transformation," J. Mater. Sci., vol. 46, pp. 855-874, 2010.

[8] X. Liu., P.K. Chu, and C. Ding, "Surface modification of titanium, titanium alloys, and related materials for biomedical applications," J. Mater. Sci. and Eng., vol. 47, pp. 49-121, 2004.

[9] Augugliaro, V. Loddo, M. Pagliaro, G. Palmisano, and L, Palmisanov, Clean by light irradiation: practical applications of supported $\mathrm{TiO}_{2}$, Cambridge: RSC Publishing, 2010, pp.2-40.

[10] Y. Han, D. Chen, J. Sun, Y. Zhang, and K. Xu, "UV-enhanced bioactivity and cell response of micro-arc oxidized titania coatings," Acta Biomater., vol. 4, pp. 1518-1529, 2008.

[11] Y. Gao, Y. Liu, L. Zhou, Z.H. Guo, M.D. Rong, X.N. Liu, C.H. Lai, and X.L. Ding," The effects of different wavelength uv photofunctionalization on micro-arc oxidized titanium," Chi. J. Stom., vol. 47, pp. 359-363, 2012.

[12] Y. Han and K. Xu, "Photoexcited formation of bone apatite-like coatings on micro-arc oxidized titanium., J. Biomed. Mater. Res. A, vol. 71, pp. 608-614, 2004.

[13] T.C. Lee, M.F.M. Rathi, M.Y.Z. Abidin, H.Z. Abdullah, and M.I Idris, "Characterisation and in vitro bioactivity of uv-treated anodised titanium," The proceeding of The $2^{\text {nd }}$ International Materials, Industrial, and Manufacturing Engineering Conference (MIMEC), in press.

[14] T.C. Lee, H.Z. Abdullah, and M.I. Idris, “Effect of uv wavelength on apatite formation of anodised titanium," The proceeding of The $2^{\text {nd }}$ International Materials, Industrial, and Manufacturing Engineering Conference (MIMEC), in press.

[15] T.C. Lee, H.Z. Abdullah, and M.I. Idris, "Effect of uv light treatment condition on apatite formation of anodised titanium," The proceeding of The $2^{\text {nd }}$ International Materials, Industrial, and Manufacturing Engineering Conference (MIMEC), in press.

[16] T. Kasuga, H. Kondo, and M. Nogami, "Apatite formation on $\mathrm{TiO}_{2}$ in simulated body fluid," J. Cryst. Growth, vol. 235 , pp. 235-240, 2002.

[17] T. Kokubo and H. Takadama, "How useful is SBF in predicting in vivo bone bioactivity?," Biomater., vol. 27, pp. 2097-2915, 2006.

[18] P. Huang, K. Xu, and Y. Han, "Formation mechanism of biomedical apatite coatings on porous titania layer," J. Mater. Sci. Mater. Med., vol. 18, pp. 457-463, 2007. 